\section{Magnetic Dicturiance}

Triere was a considerable disturbance of the maynetograph recorded here on March 15 , and had the photographic curves been developed on that day, we should probably have predicted the occurrence of the aurora seen during the evening. The carthcurrents, which are necessary concoinitants of magnetic disturbances, were probably intense enough to cause the disarrangement of the cable tests referred to by Mr. Willoughby Smith.

G. M. WHIPPLE

Kew Observatory, Richmond, Surrey, April 7

\section{The Samsams}

From a note in last week's Nature it appears that during his recont explorations in the Malay peninsula $M$. Deloueli claims to have discovered the "bitherto anknown" Samsam perplc. Allow me to state in reply that I have long been aware of the existence of these half-caste Malay and Siamese communities. They will be found duly recorcled and described at p. 642 of my ethnological appendix to the "Australasia" of the Stanford Series, published in 1879 . They appear to be now mostly Mohammedans, speaking what is called a mixed siamese and Malay dialect, and otherwise forming an ethnical transition between these two races.

University College, Gower Street, April 4

\section{A. H. KEANE}

\section{Meteor}

LAS'T evening (April 3) I saw a fine meteor at 81 . 2rm. G.M.T. ( $\pm \mathrm{im}$.). I was walking along the street at the time and looking at Algol, and so only caught sight of it during the last few moments of its apparition. Its path as observed was from a $80^{\circ}$ North $\delta 2^{\circ}$ to a $76^{\circ}$ South $\delta 4^{\circ}$, when it disappeared behind houses. It seemed quite twicc the brightness of Jupiter, and about 3 ' diameter; colour, chrome yellow; duration, three seconds. It left no visible train.

II. SADLLR

Clapham, April 4

\section{STEEL GUNS}

$\mathrm{T}$ HE whole of this part of the Proceedings of the Naval Institute is occupied by detailed accounts of the steps taken to prepare the way for the establishment of Steel Gun Factories for the United States. We are informed that, while the rest of the world has advanced with the progress of the age, the artillery of the United States has made no step forward. Artillerists and advocates for providing adequate means of defence have laboured under many difficulties during the last twenty years, while regret is expressed that personal intcrests have entered so largely into the discussion of a question of such magnitude. In the House of Representatives it was declared that the fortifications of that country were in an absolutely worthless condition for all purposes of warfare.

Early in 1882 communications were opened with the owners of the chief foundries and stecl works of the United States, but no firm could be found which had ever made steel guns.

At length the President of the United States was authorised and required to sclect six officers of their army and navy to examine and report respecting the neccssary navy-yards and arsenals. Accordingly, the President named six officers (April and, 1883 ) to form the Board of Gun Foundry, and one of their number, Lieut. W. $\mathrm{H}$. Jaques, U.S.N., was elected secretary to the board. Their report was dated February $16 \mathrm{th}, \mathrm{I} 884$. The Board found it necessary to seek information in Europe, and malke visits to England, France, and Russia, in order that they might reply satisfactorily to the Act of Congress. There they were well received, and had every facility afforded them in making; their inquiries. The aim of Lieut. Jaques, U.S.N., in his communication to the Naval Institute, was

I procelings of the United States Naval Institute, vol. x. No. 4, 4884. (The Establislment of Stecl Gun Facteries in the United States, by Lieut W. II. Jaques, U.S.N.) to show the necessity of steel gun factories to the United States, to extend the information collected, and to provide a book of easy reference to the dctails of modern ordnance. He has produced a work which ought to warn and instruct us.

The Board in their Report give an account of the introduction of the coil system of building up guns in England; of the cost of the system to this nation; of the fortypounder Armstrong, adopted for the navy in 1859 , and of the constructing of one hundred of the Iro-pounders beforc any experiments with them had been concluded.

Of four guns under trial, three showed a separation on the outside between the trumnion-ring and the coil behind it. The fourth showed a separation all round, but to less extent. All the guns expanded in the shot chamber and part of the powder chamber, and the bores were elongated. Much of these defects, no doubt, arose from excessive friction between the lead-coated projectile and the gun, which caused an unnccessary stress upon the gun.

The first visit paid by the Board was to the Elswick works. They remark: "The establishment at Elswick is thoroughly equipped for heavy work, and has produced the largest guns in the world. . . . The shops are supplied with an abundance of fine tools," page 583 . They have a hammer of thirty-five tons. "The advantages of the Whitworth manufacture are also recognised, and a forging press is being introduced."

They next visited the Woolwich Royal Gun Factories, which are stated to have had in $1873-4$ a capacity for the production of 6,000 tons of guns of various calibres per year. "The transition state in which the Board found the Woolwich gun factories is due to the change from muzzleloading to breech-loading, and the substitution of homogeneous metal for the wrought coil" (page 589). The Board give a list of the chief tools in the Arsenal, as boring machines, planing machines, \&c. There are four travelling cranes of 60 tons, six of 30 , and six of 25 tons capacity. There are also : one steam hammer of 40 tons, one of 12 tons, one of 10 tons, two of 7 tons, besides many smaller ones. The steam power in the Royal Gun Factories is supplied by forty boilers of 40 -horse power. "The plant at Woolwich, because of its transition state, contains very little worthy of imitation in planning the erection of gun factorics in the United States."

The Board next visited the works of ' $\Gamma$. Frith \& Sons, Sir John Brown \& Co., C. Cammell \& Co., and Sir H. Bessemer, all of Sheffield, and Lieut. Jaques gives full accounts of the most recent furnaces and methods employed there in working steel, illustrated with many beautiful plates. He also gives an account of the manufacture of compound armour, under the patents of Wilson \& Ellis; as well as of the trials of armour plate made at Spezzia, and of granite forts protected by iron plates at Shoebury ness in 1883

"The new departure in the system of gun construction, described farther on in this report, will demand from the Sheffield stecl manufacturers increased effort. Up to the present time the only portion in the construction of the Woolwich gun that required steel was the tube. . . The new construction requires that stcel shall be used throughout, and the castings for the jackets for guns now in hand at Woolwich can hardly be supplied from Sheffield" (page 630).

It is remarked that in one important establishment preparations were being made for the introduction of a Jarge press, to takc the place, or supplement, the work of the hammer. The Sheffield steel manufacturers are entirely sceptical as to the advantage or practicability of the compression of steel in the liquid state, and although they conccde the efficacy of forging under hydraulic compression, they consider it an objection to the process that a much higher temperature will be required for the press than for the hammer.

Sir Joseph Whitworth's works at Manchester were 
visited, where they enjoyed the privilege of carrying on their investigations within the works. "It may be distinctly asserted that the experiences enjoyed by the Board during its visit amounted to a revelation" (page 633).

"The distinguishing characteristics of the Whitworth fluid-compressed steel are homogeneity, strength, and ductility. It is made of various tempers to suit all purposes, particularly where it is exposed to sudden and violent strains. . . . No other metal possesses the same endurance" (page 633). Sir Joseph Whitworth is said to have remarked that, "Guns of enormous size are now being made at Woolwich at an enormous expenditure. . . . But if monster guns were wanted, they could be made at far less cost by means of the Siemens-Martin process and fluid compression. Supposing a hoop was wanted, say, 20 tons weight, the time required for its production would not, commencing with the raw material, he believes, be more than one-tenth the time required by the forging, coiling, and welding processes. . . . The Board witnessed the operations of casting followed by that of liquid compression, the enlarging of hoops, the drawing out of cylinders, and the forging of a solid ingot. The unanimous opinion of the members is that the system of Sir Joseph Whitworth surpasses all other methods of forging, and that it gives better promise than any other of securing that uniformity so indispensable in good gun metal" (page 642).

In France, as in England, the most friendly welcomes were tendered to the Board. The Government has obtained an immense increase of its resources by encouraging private industries. The foundry at Ruelle has become the principal, if not the only, establishment for the manufacture of the larger calibres designed for the navy and coast.

"It contains the most remarkable collection of tools of the age. They are designed for guns of $34 \mathrm{~cm}$. (1 $3{ }^{4}$ in.) and upwards, and have a capacity for handline guns of I60 tons in weight and 60 feet in length" (page 688),

"It seems as if in France the happy mean has been reached by which the Government and the private industries can work harmoniously towards the accomplishment of a national object. In a combined system of this kind, it is very important to be assured that there exist mutual checks which act to prevent one party imposing improper or hard terms on the other" (page 689).

For tubes and hoops for large guns the supply is limited to the works at St. Chamond and at Le Creusot; the former having a steam hammer of 80 tons and the latter, one of roo tons. At Le Creusot are situated the most important steel-works in France. "At no other place in the world is steel handled in such masses, and it is safe to say that no proposed work can be of such magnitude as to exceed the resources of the establishment" (page 693). There is assembled an array of steam hammers not equalled in the world. They have three cranes capable of sustaining Ioo tons, and one I6o tons. For the preparation of metal for cannon and armour-plates Le Creusot is thoroughly equipped.

Little need be said of Germany, as that country depends almost entirely upon Krupp's establishment for the supply of its guns, and the Board were not allowed to examine his works, for they were informed that the works at Essen cannot be seen, as "these are closed to all but those who have special business of inspection of war material on order." Krupp enjoys great advantages in having practising grounds at Meppen $10_{2}^{\frac{1}{2}}$ miles long, and at $\mathrm{D}$ älmen of $4 \frac{1}{2}$ miles. Near thirty years ago Krupp planned his 50 -ton hammer. $\mathrm{He}$ is constructing a I2I-ton I6-inch gun of 35 calibres length for the Italian Government.

The Russians formerly patronised Krupp, but of late they have begun to manufacture guns at home, with the assistance of private firms. Like many of the great steelworks of Europe, the establishment at Aboukhoff is in a transition state. They possess ten steam hammers, vary- ing from a $\mathrm{I}$-ton to a 50-ton. The most important improvement which has recently been introduced is Sir J Whitworth's system of liquid compression.

Certain recommendations are made respecting the production of guns for the United States. As examples of a practical partnership between a Government and a private company, in working towards a national object, the experiences in England and Russia are very instructive, and warn against the adoption of such a system. As an example of depending almost entirely on private works, Germany is a perfect instance. $A$ s an example of depending alone on Government works France was a perfect instance before the Franco-German war. "How cntirely France has now altered her system is shown in a previous part of this report; her present practice is theoretically perfect, and it has proved to be practically efficient. Her Government establishments are still retained, but as gun factories simply, in which the parts are machined and assembled, but for foundry work she depends upon the private industries of the country"' (page 843). But still the Government is careful to secure good advice in controlling these private establishments, for on one occasion it was considered desirable to require the steel to be suppliec! to be subjected to additional tests. When the steel manufacturers at home resisted this the Government gave the contract to a foreign firm which was willing to comply with their requirements.

An inquiry, instituted in 1882 , showed that the cost of steel construction in Europe was then as follows :-Krupp, 5 I to 60 cents $(26 d$. to $30 d$.) per pound; Whitworth, 38 cents (I $g d$.) per pound; Woolwich guns, $30 \frac{1}{2}$ cents ( $15 d$.) per pound ; Land service guns (France) 48 cents (24l.) per pound; but, it is added, the price of French construction has been greatly reduced (page 852 ).

From the short extracts we have been able to give from this most important and instructive work it must be apparent that the private firms in Germany and France are much in advance of those in England in respect of the magnitude of the steel-works they are able to cxecute, but only in consequence of Govcrnment encouragement and patronage. There are in those countries steam hammers in operation at least double the weight of any in use in this country. And yet, it must be rcmarked, these hammers are of English invention, and that the best armour-plates manufactured on the continent are made according to an English patent. The Bessemer process and the Siemens furnace are there much used. But it is equally plain that we have at Manchester and Sheffield several firms capable of successfully competing with the world, if they receive that support which a Government only can give.

After the failure of the rio-pounder B.L. Armstrong gun above noticed, it is remarkable how suddenly the system was abandoned. It was quite plain that the evil arose from the obstruction to the initial motion of the shot, and from the enormous friction all along the bore. But there seems to have been no rcal effort made to remedy this evil. If the lead coating did not prove satisfactory, why not rifle a condemned gun on the shunt principle and try studded shot? The original B.L. guns seem to have been much better proportioned guns than the M.L. guns which superseded them, for in a lecture delivered before the Royal United Service Institution about I 873, it is remarked that "A long B.L. 40-pounder converted into a M.L. 47-pounder is remarkable for the small amount of resistance it gives, and for its great accuracy of fire. . The regularity of the resistance of the air is also very remarkable," i.e., when compared with the shooting of service M.L. guns of the same date. There is no known reason why this gun shot so well, except from its extra length. But the hint was not attended to. And the shortness of the English M.L. guns has been often remarked. Thus at the famous contest at Tegel, in 1868 , between a 9 -inch $\mathrm{I} 2 \frac{1}{2}$-ton M.L. "Woolwich" gun costing 
$f_{1} \mathrm{I}, 500$ and a Krupp $9{ }^{1}$-inch B.L. gum of $14 \frac{1}{2}$ tons costing $£ 3,453$, the length of the former was 125.5 inches and that of the latter 157.6 inches. Great complaints were justly made of the unfairness of the comparative trial, because, while the English gun was strictly confined to service conditions, the German gun was repaired and altered so that every feature of the original combination was changed. After some months' delay Krupp raised the initial velocity of his gun from I, I I5.3 f,s. to I, 286 or I,4 I 4 f.s., according to whether a $336 \mathrm{lb}$. shot or a $275 \mathrm{lb}$. shell was used. Time has now decided this contest. Here we remark how ready Krupp's party were to notice defects and apply remedies. If the English party were debarred from effecting improvements at Tegel, they were free to improve at home. They had seen that it was possible to construct a $9^{\frac{1}{4}}$-inch B.L. gun, firing lead-coated projectiles, which could compete with an English 9-inch M.L. gun. But we do not hear of any further attempts having been made to render the 110-pounder (about 7 inch) B.L. Armstrong gun an efficient weapon.

Last spring we were informed by authority that the new B.L. gun then about to be constructed would be double the length of the old B.L. gun. And quite recently the Times intimates a doubt about some newly constructed guns having sufficient strength in front of the trunnions to resist the full charge for which they were constructed. Now some years ago we heard a good deal about the doings of a Committee on Explosives, which carricd on experiments for several years, and at last reported. What could be the use of such a committee if it did not furnish rules for properly proportioning the strength of guns, and for determining the proper length of bore required for the profitable consumption of charges of slow-burning powder? Although Rodman and the pressure gauges and chronoscopes appear to have failed to give reliable results, it would not be difficult to contrive experiments which would give the practical valuc of cvery inch in length of the bore, and at the same time show the effect of great length of bore upon the steadiness of the motion of the elongated projectile.

In October, 1883 , it was stated in the papers that some comparative trials had been made at Portsmouth before "my lords," between a Krupp and an English 6.inch B.L. gun, "greatly to the advantage of the former." $\Lambda$ Krupp gun fired a $64 \mathrm{lb}$. shot with a $14 \mathrm{lb}$. charge and the English gun a $100 \mathrm{lb}$. shot with a $34 \mathrm{lb}$. charge. That is, the charge of the Krupp gun was two-ninths, and that of the English gun three-ninths of the weight of its shot. This increased charge might be a positive disadvantage to the English gun if it was a short one. This is a case requiring the most careful and candid investigation. Any fine moming a thorough comparison of the performances of these two guns might be carried oul in a searching manner, if only known means of doing this were employed. In order to succecd in gun-making it is absolutely necessary for careful experiments to be carried out to clear up anomalies, such as we have mentioned.

This work is illustrated by seventy-eight most carefully executed plates of guns, carriages, large steam hummers, and cranes, furnaces, plans of works, \&c., and it concludes with estimates of the expenses of cquipping a gun foundry according to modern requircinents.

Ti. B.

\section{ON THE FORMATYON OF SNOW CRYSTALS} FROM FOG ON BEN NEVIS

$I^{N}$ $\mathrm{N}$ addition to the actual fall of snow, hail, \&c., there is on Ben Nevis a form of solid precipitation scarcely known on lower ground, but of almost daily occurrence here. In ordinary weather the top of the hill is enveloped in drifting fog, and when the temperature of the air and ground is below freezing this fog deposits small crystalline particles of ice on every surface that obstructs its passage.
These particles on a wall or large sloping surface, so well described in a recent letter in NATURE (vol. xxxi, p. 216), combine to form long feathery crystals; but on a post or similar small body they take a shape more like fir-cones, with the point to windward. Whether this deposition is from the vapour of the fog directly or from actual particles of frozen water carricd along in it is not very clear. The forms and arrangements of the crystals vary according to the form of the surface to which they adhere, but all belong to this feathery or cone type, the branches Iying at an angle of $30^{\circ}$ with the main axis pointing to windward. They are formed wherever the wind blows past an obstructing body. On a flat board they gather first and most abundantly near its edges, forming a most beautiful border around it ; while the centre, which I suppose the wind does not directly reach, rcmains clear. A round post, on the contrary, has an almost uniform crop of these crystals all over its windward half, and so accurately do they point to windward that it is possible to trace changes in the direction of the wind from the successive layers of crystals lying at different angles. The rate of growth varies with the density of the fog and the speed of the wind, but for the ordinary winds and fogs of this exposed position about half an inch per hour may be taken as a rough average. I have never seen it excecd two inches per hour. If there is a damp feeling in the air, if in fact it is mist that is passing rather than fog, the crystals are icy and hard; but when the temperature is well below freezing and the fog fecls comparatively dry, they are looser in texture, seem when first formed to be attached by a mere point to whatever they are on, and are pretty casily knocked off. There is practically no limit to their growth ; last winter during a long continuance of strong south-westerly winds and cold weather a post 4 inches square grew into a slab of snow some 5 feet broad and $I$ foot thick in less than a week, the crystalline mass then fell off by its own weight and a new set began to form.

The effect of this growth on all the instruments exposed to its action may be easily imagined. Nothing keeps its shape or colour. The louvres of the Stevenson's screen for the thermometers bccome serrated with rows of teeth which quickly coalesce into a solid mass completely stopping any circulation of air inside the box. The use of exposed radiation thermometers, black bulb in vacuo, \&c., is rendered wcll nigh impossible, as these delicate glass instruments would run serious risk of breakage in clearing them of the deposit, while their readings would have little value, being merely the record of the temperature inside a more or less opaque mass of snow. Very often the rain-gauge is coated with these crystals an inch thick on its windward side, while not a particle is to be seen inside. Ordinary anemometers of the type of Dr. Rubinson's cup instrument become useless; the cups are no longer hemispheres, but irregular hollow bodies bristling all over with pointed crystals, and the arms carrying them increase to many times their original thickness, thus offering much greater surface for the wind to act on. Under such circumstances the anemometer at the Observatory is usually left to its own devices, and grows into an itregular mass of snow scarcely showing any trace of its original outline, to be cleared again whern dry weather or a thaw gives it a chance of working. When the fog comes on while the ancmometer is still turning, the crys. tals form chiefly on the outside of the cups and around their edges, leaving the insides pretty clear. The arms carrying the cups get completely covercd, and on the diagonal stays supporting the arms the crystals show a beautiful "twined" structure pointing downwards and outwards on each side.

Occasionally the crystals are smokey-brown in colour instead of white. For eximple, those found on December 23 , 1884 , were distinctly brown, but on the 24 th these were overlaid by a pure white set. What causes this 